\title{
INNOVATION OF THE FEP AND SEP ACCORDING TO THE PRESENT TRENDS OF ICT EDUCATION IN PRIMARY SCHOOLS
}

\author{
Petr PEXA*, Jihočeská univerzita v Č. Budějovicích \\ Michaela $\check{C}$ APKOVÁ, Jihočeská univerzita v Č. Budějovicích
}

Přijato: 3. 9. 2018 / Akceptováno: 3. 12. 2018

Typ článku: Teoretická studie

DOI: $10.5507 /$ jtie.2018.012

Abstract: The article represents a draft of a School Education Programme (SEP), which is going to be used as an exemplary for the education of ICT in primary schools. The exemplary SEP was created in connection with a new Framework Education Programme (FEP) and according to the present trends of ICT education, based on the possibilities of the usage of modern technologies. The reworked SEP deals with the knowledge expected for students to master and the resulting learning materials in the areas of algorithms, programming, robotics, which are supposed to be taught in schools during ICT lessons.

Key words: School Education Programme, Framework Education Programme, education, ICT, primary school.

\section{INOVACE RVP A ŠVP V ZÁVISLOSTI NA AKTUÁLNÍCH TRENDECH VÝUKY ICT NA ZŠ}

Abstrakt: Článek představuje návrh školního vzdělávacího programu (ŠVP) sloužiciho jako vzor pro výuku vzdělávací oblasti Informačni a komunikačni technologie na základních školách. Vzorový ŠVP byl vytvořen $v$ souvislosti s novým rámcovým vzdělávacím programem (RVP) a v souladu se současnými žádoucími tendencemi ve vzdělávání, založenými mimo jiné na aktuálních možnostech využití modernich technologii. Návrh ŚVP se zabývá kompetencemi, kterých by měli žáci nabýt v oblastech základi̊ algoritmizace, programování, robotiky a z toho vyplývajícím učivem, jež by mělo být na školách probíráno ve výuce ICT.

Klíčová slova: školní vzdělávací program, rámcový vzdělávací program, výuka, informační a komunikační technologie, základní škola, ŠVP, RVP, ICT.

\footnotetext{
*Autor pro korespondenci: pexa@pf.jcu.cz
} 


\section{1 Úvod}

Informační technologie se pro dnešní společnost stávají stále více nepostradatelnými. Lidé se s nimi setkávají v soukromém i pracovním životě prakticky neustále, a proto je třeba se naučit, jak informační technologie fungují, k čemu je lze využít a jak s nimi pracovat. Děti začínají již na 1. stupni základních škol v rámci vzdělávací oblasti Informační a komunikační technologie či v konkrétních tematických celcích oblasti Člověk a svět práce. Související předměty neslouží pouze jako nástroje pro to, aby děti pochopily, jak ovládat počítač a pracovat s programy, ale také by měly rozvíjet jejich logické myšlení, schopnost zpracovávat informace a efektivně využívat technologie ve sfére dalších předmětů, studia i budoucího povolání, jelikož znalost ICT je základním všeobecným vzděláním moderního člověka.

Náplň výuky vzdělávací oblasti Informační a komunikační technologie v aktuálně platném RVP, ze kterého vychází ŠVP základních škol, se kromě malých obměn od roku 2005 nezměnila. Jelikož se současné technologie rychle vyvíjejí a nepřetržitě nám přinášejí něco nového, je třeba sledovat aktuální trendy a výuku informatiky (zároveň s odpovídajícími vzdělávacími dokumenty na Ž̌ , víceletých gymnáziích i dalších stupních vzdělávání) podle nich inovovat častěji a do větší hloubky, než tomu může být v některých jiných vyučovaných předmětech.

Z výše uvedeného důvodu připravila pracovní skupina z Národního ústavu pro vzdělávání pod vedením garantky pro vzdělávací oblasti Informační a komunikační technologie a Člověk a svět práce Mgr. Daniely Růžičkové v roce 2017 nový rámcový vzdělávací programu (dále jen RVP) pro oblast výuky ICT na ZŠ, jehož jednotlivá témata budou muset být respektována $\mathrm{v}$ souvisejících konkrétních školních vzdělávacích programech (dále jen ŠVP) a zpracována podle požadavků nového RVP.

\section{Cíle a metody}

Cílem článku je představit návrh vzorového ŠVP pro výuku vzdělávací oblasti Informační a komunikační technologie na základních školách a $\mathrm{v}$ odpovídajících ročnících víceletých gymnázií. Návrh ŠVP vznikl v souvislosti s představeným novým RVP a v souladu se současnými žádoucími tendencemi ve vzdělávání, opírajícími se mimo jiné o aktuální možnosti využití moderních technologií např̀. v oblastech základů algoritmizace, programování, robotiky, využití cloudových nástrojů v týmové spolupráci při realizaci projektů nebo interaktivních a hlasovacích zařizení. Pro velký rozsah nových informatických témat bude obdobně inovována i vzdělávací oblast Člověk a svět práce, resp. jeho vzdělávacího okruh Využití digitálních technologií.

Návrh ŠVP je také vypracován v rámci rozvojového projektu Podpora společenství praxe jako nástroj rozvoje klíčových kompetencí (reg. č. CZ.02.3.68/0.0/0.0 /16_011/0000660), jehož hlavním řešitelem je Univerzita Palackého v Olomouci a partnery jsou Jihočeská univerzita v Českých Budějovicích a Ostravská univerzita.

Jedním z požadovaných výstupů projektu jsou doporučení pro úpravu ŠVP všech zapojených škol v síti společenství praxe. Jak již bylo zmíněno výše, shodou okolností byl odborné veřejnosti koncem r. 2017 představen radikálně inovovaný RVP pro oblast výuky ICT, bylo tedy rozhodnuto vytvořit i z tohoto do̊vodu zcela nový návrh ŠVP pro oblast výuky ICT na základních školách a odpovídajících ročnících víceletých gymnázií.

Použité metody: analýza kurikulárních dokumentů, komparace kurikulárních dokumentů. 


\section{Kurikulární dokumenty}

Kurikulární dokumenty vznikající v souladu s Národním programem rozvoje vzdělávání v ČR (Bílá kniha) a školským zákonem (zákon č. 561/2004 Sb., o předškolním, základním, středním, vyšším odborném a jiném vzdělávání), definují cíle, obsah a samotné pojetí dané oblasti vzdělávání (Pedagogické info, 2007).

Systém kurikulárních dokumentů je tvořen dvěma úrovněmi - státní a školní. Státní úroveň obecnějšího charakteru obsahuje Národní program vzdělávání a rámcové vzdělávací programy (RVP) pro dílčí etapy vzdělávání. Úroveň školní je reprezentována již konkrétními školními vzdělávacími programy (Vlčková, 2005; Pedagogické info, 2007; MŠMT, 2016).

Všechny výše jmenované pedagogické dokumenty (včetně ŠVP škol) jsou veřejně přístupné. Celé znění RVP lze najít na webových stránkách Ministerstva školství, mládeže a tělovýchovy, ŠVP pak bývají uvedeny na webech jednotlivých škol či vyvěšeny v jejich prostorách, jelikož přesný způsob zveřejnění není zákonem stanoven (MŠMT, 2016).

\section{Rámcový vzdělávací program}

Rámcový vzdělávací program je kurikulární dokument státní úrovně vydávaný Ministerstvem školství, mládeže a tělovýchovy stanovující obecný rámec pro jednotlivé typy vzdělávání (předškolní, základní, speciální základní, gymnázia, střední odborné, základní umělecké, jazykové školy). Jedná se o závazný dokument, kterým jsou pedagogové povinni se řídit a výuku na školách podle něho realizovat prostřednictvím vytvořeného ŠVP.

RVP ZV (pro základní vzdělávání) určuje obsah vzdělávání, jeho cíle, rámcový učební plán (počet vyučovaných hodin pro jednotlivé vzdělávací oblasti) a klíčové kompetence neboli dovednosti a schopnosti získávané dětmi během celé doby vzdělávání (kompetence k učení, kompetence k řešení problémů, kompetence komunikativní, kompetence sociální a personální, kompetence občanské, kompetence pracovní), dále pak zásady při tvorbě ŠVP a podmínky vzdělávání žáků se speciálními vzdělávacími potřebami.

V hlavní části RVP ZV je popsána charakteristika a cíle jednotlivých vzdělávacích oblastí. Každá vzdělávací oblast zahrnuje témata, učivo a výstupy, které má být probráno v průběhu prvního a druhého stupně. Současná verze RVP ZV je opatřena i dodatky v podobě upravených očekávaných výstupů v rámci podpůrných opatření (Portál RVP, 2012; MŠMT, 2016).

Vzdělávací oblasti, jež se týkají povinného předmětu informatika vyučovaného na základních školách a víceletých gymnáziích, jsou Informační a komunikační technologie a Člověk a svět práce.

\section{Vzdělávací oblast Informační a komunikační technologie v dosud platném RVP}

Vzdělávací oblast Informační a komunikační technologie žákům poskytuje získání základní informační gramotnosti, což zahrnuje schopnost ovládat informační moderní technologie a efektivně zpracovávat a využívat informace. Výpočetní technika je v současné době pro většinu populace každodenní součástí, a proto se tato vzdělávací oblast stává stále více důležitou. Přesto, že jsou počítače a svět okolo nich velice populární, schopnosti a dovednosti s tímto oborem spojené se u dětí samovolně nerozvíjí tak, jak by měly. Cílem vzdělávací oblasti je docílit rozvoje schopností žáků v efektivním způsobu využívání počítače, vyhledávání informací a následném zpracování pomocí vhodných textových, grafických a dalších programů. Dalším cílem je rozvoj tvořivého algoritmického myšlení, respektování a chápání významu duševního vlastnictví či znalost rizik při využívání internetu 
v souvislosti se sociálními sítěmi či dalšími stránkami obsahujícími nevhodný obsah (MŠMT, 2016).

RVP stanovuje zařadit tuto oblast do vzdělávání s minimální časovou dotací čítající jedné vyučovací hodiny týdně na prvním a také na druhém stupni. V současném obsahu jsou na prvním stupni zahrnuty (MŠMT, 2016):

- Základy práce s počítačem (využivání standardních základních funkcí počítače a periferií, pravidla bezpečnosti spojené s HW i SW, ochrana před ztrátou a zneužitím dat),

- Vyhledávání informací a komunikace (způsoby vyhledávání informací pomocí internetu, komunikace na internetu),

- Zpracování a využití informací (textový a grafický editor).

Druhý stupeň obsahuje (MŠMT, 2016):

- Vyhledávání informací a komunikace (důvěryhodnost elektronických zdrojů, elektronická komunikace),

- Zpracování a využití informací (textové, grafické, prezentační a tabulkové programy, typografická pravidla, duševní vlastnictví).

Do sféry informatiky zasahuje také vzdělávací oblast Člověk a svět práce, resp. jeden z jeho vzdělávací obsahů - Využití digitálních technologií, který prohlubuje teoretické znalosti i praktické dovednosti v tomto odvětví. Zabývá se druhy digitální techniky, způsobem přenosu informací, využitím programů při archivaci nebo úpravě dat a také bezpečností při jejím využívání (MŠMT, 2016).

\section{6 Školní vzdělávací program}

Každá škola je povinna vytvořit svůj vlastní školní vzdělávací program vycházející z požadavků RVP, který podrobněji popisuje výuku na dané škole. Jedná se o závazný dokument, jehož náplň je nutno dodržovat, naplňovat a probíhající výuku na školách podle obsahu uzpůsobovat. Na vypracování se podílejí všichni pedagogové školy podle jejich aprobací a specializací. Hotový dokument je vydán ředitelem príislušné školy (Portál RVP, 2012; NÚV 2018).

Důvodem vytvoření vlastního ŠVP školami je možnost profilovat se v dané oblasti podle zaměření a možností škol, např. vybráním určitých tematických celků ze vzdělávací oblasti Člověk a svět práce nebo využitím disponibilních hodin na rozšíření učiva v konkrétních předmětech, kterým je poté tímto způsobem kladen větší důraz.

ŠVP musí být strukturován podle následujících kapitol, úplný výčet je obsažen v RVP ZV (Portál RVP, 2012; MŠMT 2016; NÚV 2018).

- identifikační údaje školy (základní údaje o škole, např. název, adresa, IČ, obor vzdělávání, jméno ředitele, kontakt),

- charakteristika školy (např. velikost školy, informace o pedagogickém sboru, vybavení školy, dlouhodobé projekty, způsob spolupráce s rodiči),

- $\quad$ charakteristika ŠVP (např. zaměření školy, projekty, začlenění prưřezových témat do výuky, péče o nadané žáky nebo žáky se speciálními vzdělávacími potřebami), 
- učební plán (zpracováno pomocí tabulky, např. povinné předměty, volitelné predměty, časové dotace předmětů v jednotlivých ročnících, celkové počty vyučovaných hodin),

- učební osnovy (název předmětu a jeho charakteristika, náplň učiva $\mathrm{v}$ jednotlivých ročnících, výstupy žáků, související prưřezová témata a mezipředmětové vztahy),

- hodnocení výsledků vzdělávání žáků (způsob a kritéria hodnocení žáků).

Všechny údaje uvedené v učebním plánu a osnovách jsou související, to znamená, že uvedené cíle a obsah učiva $\mathrm{v}$ rámci jednotlivých předmětů musí korespondovat $\mathrm{s}$ celkově probíraným učivem. Tematické celky musí postupně navazovat $\mathrm{v}$ průřezu všech předmětů tak, aby žáci byli schopni požadavky splnit a potřebné informace $\mathrm{v}$ navazujících tématech již znali. ŠVP má také klasifikační funkci, pedagogové hodnotí naplňování ŠVP s výsledky své práce, porovnávají s RVP a navrhují co lze zlepšit, změnit nebo upravit v dalších letech (Portál InfoEdu, 2010; Portál RVP, 2012).

\section{Nový rámcový vzdělávací program pro vzdělávací oblast ICT}

Tato kapitola uvádí obsah nového RVP pro vzdělávací oblast ICT, který vytvořila pracovní skupina pod vedením Mgr. Daniely Růžičkové, odborné garantky vzdělávacích oblastí Informační a komunikační technologie a Člověk a svět práce z Národního ústavu pro vzdělávání (NÚV). Nový RVP byl představen odborné veřejnosti koncem r. 2017, je k dispozici na webu NÚV (2018) a byl schválen vedením Ministerstva školství, mládeže a tělovýchovy 28. 8. 2018 (Respekt, 2018; NÚV 2018).

\section{Data, informace a modelování}

\section{První stupeň}

- Uvede př́íklady dat, která ho obklopují a která mu mohou pomoci lépe se rozhodnout; vyslovuje odpovědi na základě dat.

- Přri digitalizaci dat rozlišuje text, obrázek, video a audio; vybere nejvhodnější formu a výběr zdůvodní.

- Vlastními slovy popíše konkrétní situaci, určí, co k ní již ví a znázorní ji.

- Rozpozná různé modely, které reprezentují tutéž skutečnost.

\section{Druhý stupeň}

- Vysvětlí rozdíl mezi daty a informacemi; vyhodnocuje data a informace; odhaluje chyby v cizích interpretacích dat.

- Při digitalizaci zvolí formát vhodný pro přenos a uchování informací a svou volbu zdůvodní; $v$ prŕípadě potřeby vhodně kombinuje data různého typu.

- Vymezí problém a určí, jaké informace bude potřebovat $\mathrm{k}$ jeho řešení; $\mathrm{k}$ popisu použivá grafy, případně další ikonické modely.

- Zhodnotí, zda jsou v modelu všechna data potřebná $\mathrm{k}$ řešení problému; vyhledá chybu v modelu a ve vlastním modelu chybu opraví; porovná svi̊j navržený model s jinými modely $\mathrm{k}$ řešení stejného problému a vybere vhodnější, svou volbu zdůvodní. 


\section{Algoritmizace a programování}

\section{První stupeň}

- Přečte textový nebo symbolický zápis algoritmu a vysvětlí jeho jednotlivé kroky.

- Popíše jednoduchý problém, navrhne a popíše jednotlivé kroky jeho řešení.

- Upraví připravený postup pro obdobný problém; ověří správnost jím navrženého postupu, najde a opraví v něm prrípadnou chybu.

- Rozpozná různé algoritmy, které vedou ke stejným výsledkům, v blokově orientovaném programovacím jazyce sestaví program; program otestuje a opraví $\mathrm{v}$ něm př́ípadné chyby.

- Rozpozná opakující se vzory, používá opakování a připravené podprogramy, používá události ke spuštění podprogramů.

\section{Druhý stupeň}

- Po přečtení jednotlivých kroků algoritmu nebo programu vysvětlí celý postup, určí problém, který je daným algoritmem řešen.

- Rozdělí problém na jednotlivé řešitelné části a navrhne a popíše kroky $\mathrm{k}$ jejich řešení.

- Upraví daný algoritmus pro jiné problémy, ověří správnost postupu navrženého i někým jiným, najde a opraví v něm př́ípadnou chybu.

- Navrhne různé algoritmy pro řešení problému, vybere $\mathrm{z}$ více možností vhodný algoritmus pro řešený problém a svůj výběr zdůvodní.

- V blokově orientovaném programovacím jazyce sestaví přehledný program pro vyřešení zadaného problému, program otestuje a opraví v něm př́ípadné logické a běhové chyby. Použivá opakování, větvení programu, proměnné, podprogramy s parametry, používá události k paralelnímu spouštění podprogramů.

\section{Informační systémy}

\section{První stupeň}

- V přirozených systémech rozezná jednotlivé prvky a vztahy mezi nimi.

- Tř́dí a řadí objekty podle různých kritérií.

- Pro vymezený problém zaznamenává do existující evidence číselná i nečíselná data; identifikuje chyby v evidovaných datech a navrhne opravu.

\section{Druhý stupeň}

- Vysvětlí účel informačních systémů, které používá a identifikuje jejich jednotlivé systémové prvky a vztahy mezi nimi.

- Vyhledává, vkládá, upravuje data přes uživatelské rozhraní, řadí a filtruje záznamy v tabulce, využívá při práci s daty v tabulce vzorce a funkce.

- Vymezí problém a určí, zda při jeho řešení využije evidenci dat.

- Nastaví pravidla pro práci se záznamy v evidenci dat.

- Navrhne a vytvoří tabulku pro evidenci dat.

- Vede navrženou evidenci dat, sleduje dodržování stanovených pravidel a postupů, hodnotí fungování evidence, opraví chyby, případně navrhne vylepšení. 


\section{Počítač a jeho ovládání}

\section{První stupeň}

- Pojmenuje jednotlivá digitální zařízení, se kterými pracuje, vysvětlí, k čemu slouží.

- Zaznamená, zobrazí, uloží, přenese, vytiskne data.

- Rozlišuje operační systém, před-instalované a další aplikace.

- Při práci využívá ovládací prvky a nástroje OS, grafického uživatelského rozhraní a pracovní nástroje vybraných aplikací.

- Rozezná způsob propojení digitálních zařízení.

- Propojí digitální zařizení, $\mathrm{k}$ digitálním datům přistupuje i na vzdálených počítačích a spouští online aplikace.

- Rozezná nestandardní chování digitálních zařízení a požádá o pomoc.

- Dodržuje pravidla stanovená pro práci s digitálními technologiemi. Respektuje bezpečnostní nastavení digitálních zařízení, se kterými pracuje, rozezná podezřelé situace a informace na internetu a požádá o pomoc dospělou osobu.

- Vysvětlí rozdíly identity ve fyzickém a digitálním světě, vybírá informace, které o sobě může zveřejnit.

- Uvádí př́klady využití digitálních technologií v různém kontextu, zhodnotí výhody využití jednotlivých digitálních zařízení pro svou práci.

\section{Druhý stupeň}

- Určí charakteristické parametry počítačů typických částí počítačových soustav.

- Využívá paměti, běžná vstupní a výstupní zařízení počítačových soustav.

- Popíše typické úkoly OS jako prostředníků mezi uživatelem a počítačem.

- Cíleně přizpůsobí uživatelské prostředí osobním potřebám, použije odpovídající si nástroje $\mathrm{v}$ různých aplikacích.

- Uvede příklady sítí a popíše jejich charakteristické znaky, vybírá nejvhodnější způsob k připojení digitálních zařízení do počítačové sítě.

- Nastavuje oprávnění pro přístup ke sdíleným datům ze vzdálených počítačů i online aplikací.

- Poradí si s typickými závadami a chybovými stavy počítačů.

- Vysvětlí možnosti a omezení technických a programových zabezpečovacích řešení, a dokáže usměrnit svoji činnost tak, aby minimalizoval riziko ztráty či zneužití dat.

- $\quad \mathrm{S}$ vědomím odlišnosti mezi fyzickým a digitálním světem vytváří a spravuje svoji digitální identitu.

- Orientuje se ve vývoji digitálních technologií a popíše, jak změny ovlivnily postupy v běžném životě, u předpokládaných trendů zhodnotí přínos a rizika změn.

\section{Porovnání dosud platného a nového RVP}

Následující kapitola se zabývá odlišnostmi náplně předmětu Informatika vycházející z komparace dosud platného RVP ZV a nově renovovaného RVP ZV (obsah uveden $\mathrm{v}$ předchozí kapitole), který zásadně mění požadavky na tento předmět.

Především je třeba konstatovat, že změna náplně výuky informatiky je značná, respektive nově vzniklý RVP je obohacen o vzdělávací obsah, který v předešlém RVP vůbec 
nebyl, rovněž je obsah podrobněji popsán. Témata spojená s informatikou jsou rozdělena do dvou částí, a to na Informatiku (týká se prímo předmětu informatika a obsahuje oborové výstupy) a Digitální gramotnost (dotýká se spíše společenských a obecnějších témat, se kterými se žáci běžně setkávají a která by se měli naučit prostřednictvím jiných předmětů).

Nový RVP člení informatiku na čtyři části:

- Data, informace a modelování,

- Algoritmizace a programování,

- Informační systémy,

- Počítač a jeho ovládání.

Data, informace a modelování rozšiřuje výuku o téma modelování (vytváření modelů, oprava modelů podle kritérií, apod.). Zůstávají témata seznamující žáky s formáty dat, informacemi, daty a grafickým znázorněním dat prostřednictvím grafü, na které by měl být ale kladen větší důraz, a např́íklad problematika různých možností grafů by měla být probírána podstatně hlouběji.

Algoritmizace a programování je kompletně nově zařazeno pro první i druhý stupeň. Žáci se zde zabývají návrhem a tvorbou algoritmů, učí se rozumět jednotlivým krokům postupu, vytvořené postupy zobecňují pro obdobné problémy, pracují ve vhodném programovacím jazyce určenému dětem, kde využívají proměnné, opakování, větvení, apod.

Informační systémy rozšiřují výuku o témata, která jsou věnovaná informačním systémům (např̀. praktickým př́íkladům, účelu, částem informačních systémů, atd.). Téma spojené s tvorbou tabulek a následnou evidencí dat pomocí např. filtrace dat, vzorců a funkcí se objevuje již v předešlém RVP.

Počítač a jeho ovládání se zabývá základními parametry počítače, využitím paměti a periferií, základními funkcemi operačního systému, přizpůsobení uživatelského prostředí, řešením závad a bezpečností při využivání digitálních technologií (v předešlém RVP uvedeno $\mathrm{v}$ tématu Základy práce s počítačem. Novým tématem jsou sítě, jejich druhy a způsob zapojení a také vývoj digitálních technologií ( $\mathrm{v}$ předešlém RVP lze zařadit do Využití digitálních technologií vzdělávací oblasti Člověk a svět práce).

Druhá část pojmenovaná Digitální gramotnost zahrnuje:

- Člověk, společnost a digitální technologie,

- Tvorba digitálního obsahu,

- Informace, sdílení a komunikace v digitálním světě.

Člověk, společnost a digitální technologie se zabývá druhy digitálních technologií a jejich využitím v běžném životě. Digitální technologie také žáci probírají prakticky (umí tedy technologie nastavovat, využívat či opravovat při běžných technických problémech), svá data umí chránit před zneužitím. Digitální technologie žáci využívají k vlastnímu vzdělávání, např. tvorbou výukových materiálů s dodržováním autorských práv. Vytvořené materiály různého druhu sdílejí s ostatními. Tento obor zahrnuje podstatnou část Využití digitálních technologií vzdělávací oblasti Člověk a svět práce. Téma spojené se sdílením informací spadá v minulém RVP pod vzdělávací obsah Vyhledávání informací a komunikace ve vzdělávací oblasti ICT. 
Tvorba digitálního obsahu spadá v minulém RVP do vzdělávacího obsahu Zpracování a využití informací. Zahrnuje vytváření a úpravu digitálního obsahu pomocí textů, tabulek, prezentací, grafiky a multimédií.

Informace, sdílení a komunikace v digitálním světě objasňuje význam informací, způsoby jejich vyhledávání podle konkrétních kritérií, zabývá se věrohodností a důvěryhodností nalezených informací. Žáci sdílejí informace různými způsoby podle účelu (skupinová práce, přeposlání hotového projektu, apod.). Obsah je analogií Vyhledávání informací a komunikace (vzdělávací oblasti ICT) obohacenou o aktuální komunikační možnosti.

\section{Návrh vzorového ŠVP pro vzdělávací oblast ICT}

Návrh podoby vzorového ŠVP ve výuce informatiky pro první a druhý stupeň základní školy vychází z nového RVP uvedeného v kapitole 7 , který značně mění požadavky a náplň tohoto předmětu. Návrh zahrnuje obsah vzdělávání, výstupy žáků a související klíčové kompetence. Návrh ŠVP vychází z předpokladu, že informatika se podle nového RVP bude vyučovat tři hodiny na prvním a čtyři hodiny na druhém stupni (časová dotace byla aktuálně schválena vedením MŠMT 13.11.2018).

\section{ICT - charakteristika vzdělávací oblasti}

Díky vzdělávací oblasti Informační a komunikační technologie žáci rozvíjí logické myšlení, získávají schopnost řešit problémy systematickým postupem a v neposlední řadě také dovednosti spojené s ovládáním digitálních technologií, orientaci ve světě velkého množství dat a informací, které využívají a zpracovávají za účelem dalšího využití.

V současné době je znalost ICT nezbytnou součástí vzdělání mladých absolventů základních škol. Informatika je žádaná na trhu práce, ve vzdělávání i každodenním životě, kde ji určitou formou využíváme v podstatě neustále.

Přehled časové dotace (schváleno MŠMT 13. 11. 2018):

- První stupeñ - 3., 4. a 5. ročník - vždy 1 hodina týdně

- Druhý stupeň - 6., 7., 8. a 9. ročník - vždy 1 hodina týdně

\section{Charakteristika předmětu}

Předmět Informační a komunikační technologie rozvíjí logické myšlení žáků prostř̌ednictvím základů algoritmizace, programování a modelování. Dalším piliřřem je dosažení základní úrovně informační gramotnosti, respektive dovednosti spojené s ovládáním počítače a dalších digitálních technologií, prací s daty a informacemi, které žáci využívají ve vzdělávání i dalších aktivitách.

První stupeň je zaměřen na využivání digitálních technologií, rozlišování a využívání informací, princip informačních systémů a základy programování. Druhý stupeň jednotlivá témata rozvíjí do větší hloubky, např. konkrétnější využití a popis informačních systémů, evidence dat, rozšířené využití digitálních technologií, pokročilejší a obtižňější postupy při algoritmizaci a blokově orientovaném programování.

Důraz je kladen na praktické využití, např. při práci s digitálními technologiemi. Při práci s daty a informacemi je dbáno na uvědomění si různých rizik žáky, na což navazuje bezpečné a obezřetné chování při využívání internetu, sociálních sítí nebo sdílení dat. 


\section{Klíčové kompetence}

Kompetence k učení

- Z Źák vyhledává a třídí informace a na základě jejich pochopení, propojení a systematizace je efektivně využívá v procesu učení, tvưrčích činnostech a praktickém životě.

- Z Žák operuje s obecně užívanými termíny, znaky a symboly, uvádí věci do souvislostí; propojuje do širších celků poznatky z různých vzdělávacích oblastí a na základě toho si vytváří komplexnější pohled na matematické, prrírodní, společenské a kulturní jevy.

Kompetence $\mathrm{k}$ řešení problémů

- Z Žák vnímá nejrůznější problémové situace ve škole i mimo ni, rozpozná a pochopí problém.

- Z Žák vyhledá informace vhodné k řešení problému, nachází jejich shodné, podobné a odlišné znaky, využívá získané vědomosti a dovednosti k objevování různých variant řešení.

- Z Žák samostatně řeší problémy; volí vhodné způsoby řešení; užívá při řešení problémů logické, matematické a empirické postupy.

- Z Žák ověřuje prakticky správnost řešení problémů a osvědčené postupy aplikuje při řešení obdobných nebo nových problémových situací, sleduje vlastní pokrok při zdolávání problémů.

Kompetence komunikativní

- Z Žák formuluje a vyjadřuje své myšlenky a názory v logickém sledu, vyjadřuje se výstižně, souvisle a kultivovaně v písemném i ústním projevu.

- Z Źák rozumí různým typům textů, záznamů, obrazových materiálů a jiných informačních a komunikačních prostředků.

- Z Žák využívá informační a komunikační prostředky a technologie pro kvalitní a účinnou komunikaci s okolním světem.

Kompetence sociální a personální

- Ž́ák účinně spolupracuje ve skupině.

- $\quad$ Žák v př́ípadě potřeby poskytne pomoc nebo o ni požádá.

Kompetence občanská

- Z Žák chápe základní principy, na nichž spočívají zákony a společenské normy, je si vědom svých práv a povinností ve škole i mimo školu.

Kompetence pracovní

- Žák používá bezpečně a účinně nástroje a vybavení. 


\section{Vzdělávací obsah}

\section{První stupeň}

\section{3. ročník}

\begin{tabular}{|c|c|}
\hline \multicolumn{2}{|l|}{ Počítač a jeho ovládání } \\
\hline Výstupy & Učivo \\
\hline \multirow{3}{*}{$\begin{array}{l}\text { Žák rozlišuje operační systém, předinsta- } \\
\text { lované a další aplikace. }\end{array}$} & Význam operačního systému, funkce \\
\hline & $\begin{array}{l}\text { Využití základních aplikací (např. kalku- } \\
\text { lačka, poznámkový blok) }\end{array}$ \\
\hline & Možnosti nalezení a otevření programu \\
\hline \multirow{2}{*}{$\begin{array}{l}\text { Žák při práci využivá ovládací prvky } \\
\text { a nástroje OS, grafického uživatelského } \\
\text { rozhraní a pracovní nástroje vybraných } \\
\text { aplikací. }\end{array}$} & Práce s ikonami \\
\hline & Práce v menu a hlavním panelu \\
\hline
\end{tabular}

\begin{tabular}{|c|c|}
\hline \multicolumn{2}{|l|}{ Algoritmizace a programování } \\
\hline Výstupy & Učivo \\
\hline \multirow{3}{*}{$\begin{array}{l}\text { Žák prrečte textový nebo symbolický zá- } \\
\text { pis algoritmu a vysvětlí jeho jednotlivé } \\
\text { kroky. }\end{array}$} & Konkretizace postupů z běžného života \\
\hline & Rozčleňování celku na jednotlivé kroky \\
\hline & Porozumění krokům postupu \\
\hline \multirow[t]{2}{*}{$\begin{array}{l}\text { Žák popíše jednoduchý problém, navrhne } \\
\text { a popiše jednotlivé kroky jeho řešení. }\end{array}$} & $\begin{array}{l}\text { Dodržování pravidel při tvorbě postupu } \\
\text { (časový sled, návaznost) }\end{array}$ \\
\hline & $\begin{array}{l}\text { Různý způsob znázornění postupu (tex- } \\
\text { tově, graficky) }\end{array}$ \\
\hline $\begin{array}{l}\text { Žák v blokově orientovaném programo- } \\
\text { vacím jazyce sestaví program. }\end{array}$ & Napsání jednoduchého programu \\
\hline \multirow{3}{*}{$\begin{array}{l}\text { Žák rozpozná opakující se vzory, používá } \\
\text { opakování a události ke spuštění podpro- } \\
\text { gramů. }\end{array}$} & $\begin{array}{l}\text { Napsání programu efektivnější cestou } \\
\text { (opakování) }\end{array}$ \\
\hline & $\begin{array}{l}\text { Různé možnosti spuštění vytvořeného } \\
\text { programu }\end{array}$ \\
\hline & Paralelní spuštění více částí programu \\
\hline \multicolumn{2}{|l|}{ Data, informace a modelování } \\
\hline Výstupy & Učivo \\
\hline \multirow{2}{*}{$\begin{array}{l}\text { Žák vlastními slovy popíše konkrétní si- } \\
\text { tuaci, určí, co k ní již ví a znázorní ji. }\end{array}$} & Popis postupu řešení běžných situací \\
\hline & $\begin{array}{l}\text { Vytvoření myšlenkových map a jejich } \\
\text { čtení }\end{array}$ \\
\hline
\end{tabular}

\section{4. ročník}

\begin{tabular}{|l|l|}
\hline \multicolumn{2}{|l|}{ Algoritmizace a programování } \\
\hline Výstupy & Učivo \\
\hline Žák popíše jednoduchý problém, navrhne & $\begin{array}{l}\text { Textové a grafické znázorňování algo- } \\
\text { ritmů }\end{array}$ \\
\hline
\end{tabular}




\begin{tabular}{l|l|}
\hline $\begin{array}{l}\text { Žák v blokově orientovaném programo- } \\
\text { vacím jazyce sestaví program; program } \\
\text { otestuje a opraví v něm př́ípadné chyby. }\end{array}$ & $\begin{array}{l}\text { Napsání jednoduchého programu dle sta- } \\
\text { novených kritérií }\end{array}$ \\
\hline $\begin{array}{l}\text { Žák rozpozná opakující se vzory, používá } \\
\text { opakování a připravené podprogramy, } \\
\text { používá události ke spuštění podpro- } \\
\text { gramů. }\end{array}$ & Napsání programu s využitím opakování \\
\cline { 2 - 2 } $\begin{array}{l}\text { Žák rozpozná různé algoritmy, které ve- } \\
\text { dou ke stejným výsledkům. }\end{array}$ & $\begin{array}{l}\text { Porovnávání algoritmického postupu } \\
\text { a výstupu }\end{array}$ \\
\hline
\end{tabular}

\begin{tabular}{|c|c|}
\hline \multicolumn{2}{|l|}{ Data, informace a modelování } \\
\hline Výstupy & Učivo \\
\hline $\begin{array}{l}\text { Žák vlastními slovy popíše konkrétní si- } \\
\text { tuaci, určí, co k ní již ví a znázorní ji. }\end{array}$ & $\begin{array}{l}\text { Popis situace či postupu grafickým řeše- } \\
\text { ním }\end{array}$ \\
\hline $\begin{array}{l}\text { Žák při digitalizaci dat rozlišuje text, ob- } \\
\text { rázek, video a audio. }\end{array}$ & $\begin{array}{l}\text { Využití různých druhů dat podle účelů ve } \\
\text { vzdělávání i dalších aktivitách }\end{array}$ \\
\hline \multirow{3}{*}{$\begin{array}{l}\text { Žák uvede př́klady dat, která ho obklo- } \\
\text { pují a která mu mohou pomoci lépe se } \\
\text { rozhodnout; vyslovuje odpovědi na zá- } \\
\text { kladě dat. }\end{array}$} & Různé zdroje dat (noviny, TV, internet) \\
\hline & $\begin{array}{l}\text { Rychlost, věrohodnost, důležitost poskyt- } \\
\text { nutých dat }\end{array}$ \\
\hline & Vyhledávání dat \\
\hline
\end{tabular}

\begin{tabular}{|c|c|}
\hline \multicolumn{2}{|l|}{ Počítač a jeho ovládání } \\
\hline Výstupy & Učivo \\
\hline \multirow[t]{2}{*}{$\begin{array}{l}\text { Žák zaznamená, zobrazí a uloží, přenese } \\
\text { a vytiskne data. }\end{array}$} & $\begin{array}{l}\text { Druhy úložných zařízení (lokální disk, } \\
\text { externí disk, flash disk, sítový disk, } \\
\text { cloud) }\end{array}$ \\
\hline & Tisk, nastavení tisku \\
\hline $\begin{array}{l}\text { Žák pojmenuje jednotlivá digitální zaří- } \\
\text { zení, se kterými pracuje, vysvětlí k čemu } \\
\text { slouží. }\end{array}$ & $\begin{array}{l}\text { Digitální zařízení - Fotoaparát, kamera, } \\
\text { počítač, televize, mobilní telefon, chytré } \\
\text { hodinky }\end{array}$ \\
\hline \multirow{2}{*}{$\begin{array}{l}\text { Žák rozezná způsob propojení digitálních } \\
\text { technologií. }\end{array}$} & Drátové propojení \\
\hline & $\begin{array}{l}\text { Druhy bezdrátového propojení (Blueto- } \\
\text { oth, Wifi) }\end{array}$ \\
\hline \multirow{2}{*}{$\begin{array}{l}\text { Žák rozezná nestandardní chování digi- } \\
\text { tálních zařízení a požádá o pomoc. }\end{array}$} & Standardní nastavení digitálních zařízení \\
\hline & Časté závady a jejich řešení \\
\hline \multirow{2}{*}{$\begin{array}{l}\text { Žák dodržuje řád a pravidla stanovená } \\
\text { pro práci s digitálními technologiemi } \\
\text { a respektuje bezpečnostní nastavení digi- } \\
\text { tálních zařízení. }\end{array}$} & $\begin{array}{l}\text { Hygienická a ergonomická pravidla při } \\
\text { práci s digitálními technologiemi }\end{array}$ \\
\hline & Bezpečnost při využívání DT \\
\hline
\end{tabular}

\begin{tabular}{|l|l|}
\hline Informační systémy & Učivo \\
\hline Výstupy & $\begin{array}{l}\text { Druhy systémů (jídelna, obchod, škola, } \\
\text { přihlášení do hry) }\end{array}$ \\
\hline $\begin{array}{l}\text { Žák v přirozených systémech rozezná } \\
\text { jednotlivé prvky a vztahy mezi nimi. }\end{array}$
\end{tabular}




\begin{tabular}{|l|l|}
\hline & $\begin{array}{l}\text { Prvky systémů a vztahy mezi nimi (koo- } \\
\text { perace, závislost, hierarchie) }\end{array}$ \\
\hline \multirow{2}{*}{$\begin{array}{l}\text { Žák tř́dí a řadí objekty podle různých } \\
\text { krité. }\end{array}$} & $\begin{array}{l}\text { Nadřazenost a podřazenost objektů (např. } \\
\text { druhy dopravy, potravní řetězec) }\end{array}$ \\
\cline { 2 - 2 } & $\begin{array}{l}\text { Důležitost a význam jednotlivých prvků } \\
\text { v systému }\end{array}$ \\
\hline
\end{tabular}

\section{5. ročník}

\begin{tabular}{|c|c|}
\hline \multicolumn{2}{|l|}{ Algoritmizace a programování } \\
\hline Výstupy & Učivo \\
\hline \multirow{2}{*}{$\begin{array}{l}\text { Žák v blokově orientovaném programo- } \\
\text { vacím jazyce sestaví program; program } \\
\text { otestuje a opraví v něm případné chyby. }\end{array}$} & Napsání jednoduchého programu \\
\hline & $\begin{array}{l}\text { Testování funkčnosti programu při vstup- } \\
\text { ních změnách (např. počáteční pozice) }\end{array}$ \\
\hline $\begin{array}{l}\text { Žák popíše jednoduchý problém, navrhne } \\
\text { a popíše jednotlivé kroky jeho řešení. }\end{array}$ & $\begin{array}{l}\text { Rozčleňování požadovaného výsledku na } \\
\text { jednodušší části }\end{array}$ \\
\hline \multirow[t]{2}{*}{$\begin{array}{l}\text { Žák rozpozná různé algoritmy, které ve- } \\
\text { dou ke stejným výsledkům. }\end{array}$} & $\begin{array}{l}\text { Porovnávání algoritmického postupu } \\
\text { a výsledku }\end{array}$ \\
\hline & $\begin{array}{l}\text { Posuzování algoritmů podle různých hle- } \\
\text { disek (přehlednost, rychlost) }\end{array}$ \\
\hline \multirow{3}{*}{$\begin{array}{l}\text { Žák upraví připravený postup pro ob- } \\
\text { dobný problém; ověří správnost jím na- } \\
\text { vrženého postupu, najde a opraví v něm } \\
\text { případnou chybu. }\end{array}$} & $\begin{array}{l}\text { Modifikace algoritmů pro řešení podob- } \\
\text { ných problémů }\end{array}$ \\
\hline & Ošetření všech chybných variant \\
\hline & $\begin{array}{l}\text { Správná časová návaznost, logický sled } \\
\text { událostí }\end{array}$ \\
\hline \multirow{3}{*}{$\begin{array}{l}\text { Žák rozpozná opakující se vzory, pou- } \\
\text { žívá opakování a připravené podpro- } \\
\text { gramy, používá události ke spuštění pod- } \\
\text { programů. }\end{array}$} & $\begin{array}{l}\text { Efektivnější programování s využitím } \\
\text { opakování }\end{array}$ \\
\hline & $\begin{array}{l}\text { Jednodušší využití parametrů při práci } \\
\text { s bloky }\end{array}$ \\
\hline & Spuštění programu a upravení parametrů \\
\hline
\end{tabular}

\begin{tabular}{|l|l|}
\hline Data, informace a modelování \\
\hline Výstupy & Učivo \\
\hline \multirow{2}{*}{$\begin{array}{l}\text { Žák rozpozná různé modely, které repre- } \\
\text { zentují tutéž skutečnost. }\end{array}$} & Druhy modelů reprezentující informace \\
\cline { 2 - 2 } & $\begin{array}{l}\text { Porovnávání stejných dat v různých mo- } \\
\text { delech }\end{array}$ \\
\cline { 2 - 2 } & $\begin{array}{l}\text { Výhody a nevýhody využití různých mo- } \\
\text { delů }\end{array}$ \\
\hline $\begin{array}{l}\text { Žák při digitalizaci dat rozlišuje text, ob- } \\
\text { rázek, video a audio; vybere nejvhodnější } \\
\text { formu a výběr zdůvodní. }\end{array}$ & $\begin{array}{l}\text { Výhody a nevýhody jednotlivých druhů } \\
\text { dat }\end{array}$ \\
\cline { 2 - 2 } & Př́ílady využití konkrétních druhů dat \\
\hline
\end{tabular}

\begin{tabular}{|l|l|}
\hline Informační systémy & Učivo \\
\hline Výstupy & Evidence dat pomocí tabulky \\
\hline
\end{tabular}




\begin{tabular}{l|l|}
\hline \multirow{2}{*}{$\begin{array}{l}\text { Žák pro vymezený problém zazname- } \\
\text { nává do existující evidence číselná i nečí- }\end{array}$} & Význam dat v tabulce \\
\cline { 2 - 2 } $\begin{array}{l}\text { selná data; identifikuje chyby v evidova- } \\
\text { ných datech a navrhne opravu. }\end{array}$ & $\begin{array}{l}\text { Zamezení vzniku chyb (význam řádků } \\
\text { a sloupců, duplikace dat, špatný formát) }\end{array}$ \\
\cline { 2 - 2 } & $\begin{array}{l}\text { Př́ḱklady praktického využití databázo- } \\
\text { vých systémů v životě }\end{array}$ \\
\hline
\end{tabular}

\begin{tabular}{|c|c|}
\hline \multicolumn{2}{|l|}{ Počítač a jeho ovládání } \\
\hline Výstupy & Učivo \\
\hline \multirow{2}{*}{$\begin{array}{l}\text { Žák při práci využívá ovládací prvky } \\
\text { a nástroje OS, grafického uživatelského } \\
\text { rozhraní a pracovní nástroje vybraných } \\
\text { aplikací. }\end{array}$} & Nastavení plochy \\
\hline & Orientace v souborovém systému \\
\hline \multirow[t]{3}{*}{ Žák zaznamená, zobrazí a uloží data. } & $\begin{array}{l}\text { Správce souborů (hierarchie souborů } \\
\text { a složek) }\end{array}$ \\
\hline & $\begin{array}{l}\text { Správce souborů (skládání a otvírání sou- } \\
\text { borů) }\end{array}$ \\
\hline & $\begin{array}{l}\text { Správce souborů (kopírování, přesouvání, } \\
\text { mazání dat) }\end{array}$ \\
\hline $\begin{array}{l}\text { Žák rozezná způsob propojení digitálních } \\
\text { technologií. }\end{array}$ & $\begin{array}{l}\text { Druhy propojení DT (drátové - konek- } \\
\text { tory, bezdrátové - nastavení) }\end{array}$ \\
\hline \multirow{3}{*}{$\begin{array}{l}\text { Žák propojí digitální zařízení, k digitál- } \\
\text { ním datům přistupuje i na vzdálených } \\
\text { počítačích a spouští online aplikace. }\end{array}$} & $\begin{array}{l}\text { Praktické propojení DT (např. PC a foto- } \\
\text { aparát, kamera }=>\text { přesun dat) }\end{array}$ \\
\hline & $\begin{array}{l}\text { Cloudové služby (druhy, využití, výhody, } \\
\text { nevýhody) }\end{array}$ \\
\hline & $\begin{array}{l}\text { Nainstalovaná vs. online aplikace (spuš- } \\
\text { tění, ukládání, místo na disku) }\end{array}$ \\
\hline \multirow{2}{*}{$\begin{array}{l}\text { Žák uvádí př́íklady využití digitálních } \\
\text { technologií v různém kontextu, zhodnotí } \\
\text { výhody a využití jednotlivých digitálních } \\
\text { zařízení pro svou práci. }\end{array}$} & $\begin{array}{l}\text { Využití DT (vzdělávání, zaměstnání, zá- } \\
\text { bava) }\end{array}$ \\
\hline & $\begin{array}{l}\text { Další využití DT (zdravotnictví, handica- } \\
\text { povaní, věda) }\end{array}$ \\
\hline \multirow{3}{*}{$\begin{array}{l}\text { Žák při digitalizaci dat rozlišuje text, ob- } \\
\text { rázek, video a audio; vybere nejvhodnější } \\
\text { formu a výběr zdůvodní. }\end{array}$} & $\begin{array}{l}\text { Výhody a nevýhody jednotlivých druhů } \\
\text { dat }\end{array}$ \\
\hline & Př́iklady využití konkrétních druhů dat \\
\hline & $\begin{array}{l}\text { Hrozby spojené s využíváním DT (ma- } \\
\text { sová média, terorismus, kyberstalking, } \\
\text { kyberšikana) }\end{array}$ \\
\hline
\end{tabular}

\section{Druhý stupeň \\ 6. ročník}

\begin{tabular}{|l|l|}
\hline Počítač a jeho ovládání \\
\hline Výstupy & Učivo \\
\hline Žák využívá běžná vstupní a výstupní za- & $\begin{array}{l}\text { Vstupní zařizení (myš, klávesnice, scan- } \\
\text { ner, mikrofon) }\end{array}$ \\
\cline { 2 - 2 } ř́zení počitačových soustav. & $\begin{array}{l}\text { Výstupní zařízení (tiskárna, monitor, re- } \\
\text { produktory) }\end{array}$ \\
\hline
\end{tabular}




\begin{tabular}{|c|c|}
\hline & Připojení periferií \\
\hline \multirow{2}{*}{$\begin{array}{l}\text { Žák přizpůsobí uživatelské prostředí } \\
\text { svým potřebám, použije odpovídající si } \\
\text { nástroje v různých aplikacích. }\end{array}$} & $\begin{array}{l}\text { Nastavení pracovní plochy, hlavního pa- } \\
\text { nelu, složek }\end{array}$ \\
\hline & Druhy programů pro stejnou práci \\
\hline \multirow{3}{*}{$\begin{array}{l}\text { Žák s vědomím odlišnosti mezi fyzickým } \\
\text { a digitálním světem vytváŕí a spravuje } \\
\text { svoji digitální identitu. }\end{array}$} & Bezpečnost na internetu \\
\hline & Slušné chování na internetu \\
\hline & Sociální sítě \\
\hline \multirow{3}{*}{$\begin{array}{l}\text { Žák nastavuje oprávnění pro přístup ke } \\
\text { sdíleným datům ze vzdálených počítačủ } \\
\text { i z online aplikací. }\end{array}$} & Cloudové služby \\
\hline & Nastavování práv \\
\hline & Možnosti skupinové práce \\
\hline \multirow{3}{*}{$\begin{array}{l}\text { Žák vysvětlí možnosti a omezení tech- } \\
\text { nických a programových zabezpečova- } \\
\text { cích řešení, usměrňuje svou činnost tak, } \\
\text { aby minimalizoval riziko ztráty či zneu- } \\
\text { żití dat. }\end{array}$} & Nastavování bezpečných hesel \\
\hline & $\begin{array}{l}\text { Rizika využivání internetových služeb } \\
\text { (finance, osobní data, důležitá data) }\end{array}$ \\
\hline & Zálohování dat \\
\hline \multirow{2}{*}{$\begin{array}{l}\text { Žák si poradí s typickými závadami } \\
\text { a chybovými stavy počítačú. }\end{array}$} & Správce úloh \\
\hline & Nedostatek místa na disku \\
\hline
\end{tabular}

\begin{tabular}{|l|l|}
\hline Algoritmizace a programování \\
\hline Výstupy & Učivo \\
\hline Žák v blokově orientovaném programo- & Napsání programu podle zadání \\
\cline { 2 - 2 } vacím jazyce sestaví přehledný program & Různé způsoby sestavení programu, \\
pro vyřešení zadaného problému. Žák & cykly (využití opakování) \\
\cline { 2 - 2 } $\begin{array}{l}\text { použivá opakování, proměnné a větvení } \\
\text { programu. }\end{array}$ & Proměnné \\
\cline { 2 - 2 } $\begin{array}{l}\text { Žák rozdělí problém na jednotlivé řeši- } \\
\text { telné části a navrhne a popíše kroky k je- }\end{array}$ & $\begin{array}{l}\text { Tvorba komplexnějších programů (po- } \\
\text { stup dělen na dílčí, jednodušśí části) }\end{array}$ \\
\cline { 2 - 2 } jich řešení. & $\begin{array}{l}\text { Popis běžň se vyskytujících situací po- } \\
\text { mocí kroků algoritmu }\end{array}$ \\
\hline
\end{tabular}

\begin{tabular}{|c|c|}
\hline \multicolumn{2}{|l|}{ Informační systémy } \\
\hline Výstupy & Učivo \\
\hline \multirow{4}{*}{$\begin{array}{l}\text { Žák vysvětlí účel informačních systémů, } \\
\text { které použivá a identifikuje jejich jednot- } \\
\text { livé systémové prvky a vztahy mezi } \\
\text { nimi. }\end{array}$} & $\begin{array}{l}\text { Druhy a využití běžných informačních } \\
\text { systémů }\end{array}$ \\
\hline & Popis prvků informačních systémů \\
\hline & $\begin{array}{l}\text { Vztahy mezi prvky informačních sys- } \\
\text { témů }\end{array}$ \\
\hline & Tvorba diagramů \\
\hline $\begin{array}{l}\text { Žák vyhledává, vkládá a upravuje data } \\
\text { přes uživatelské rozhraní. }\end{array}$ & $\begin{array}{l}\text { Orientace } \mathrm{v} \text { prostředí běžných informač- } \\
\text { ních systémů }\end{array}$ \\
\hline $\begin{array}{l}\text { Žák vymezí problém a určí, zda při jeho } \\
\text { řešení využije evidenci dat. }\end{array}$ & $\begin{array}{l}\text { Vlastní návrh informačního systémů } \\
\text { (prvky a vztahy mezi nimi) }\end{array}$ \\
\hline
\end{tabular}

Data, informace a modelování

\begin{tabular}{|l|l}
\hline Výstupy & Učivo
\end{tabular}




\begin{tabular}{|l|l|}
\hline $\begin{array}{l}\text { Žák při digitalizaci zvolí formát vhodný } \\
\text { pro přenos a uchovávání informací a }\end{array}$ & $\begin{array}{l}\text { Formáty podle typu dat (text, audio, vi- } \\
\text { deo, grafika) }\end{array}$ \\
\cline { 2 - 2 } $\begin{array}{l}\text { Svou volbu zdůvodní. } \\
\text { Textové formáty (druhy, využití, výhody, } \\
\text { nevýhody) }\end{array}$ \\
\cline { 2 - 2 } & $\begin{array}{l}\text { Grafické formáty (druhy, využití, vý- } \\
\text { hody, nevýhody) }\end{array}$ \\
\cline { 2 - 2 } & Změna formátu \\
\hline
\end{tabular}

\section{7. ročník}

\begin{tabular}{|c|c|}
\hline \multicolumn{2}{|l|}{ Data, informace a modelování } \\
\hline Výstupy & Učivo \\
\hline \multirow{5}{*}{$\begin{array}{l}\text { Žák při digitalizaci zvolí formát vhodný } \\
\text { pro přenos a uchovávání informací } \\
\text { a svou volbu zdůvodní; v prŕpadě potřeby } \\
\text { vhodně kombinuje data různého typu. }\end{array}$} & $\begin{array}{l}\text { Formáty podle typu dat (text, audio, vi- } \\
\text { deo, grafika) }\end{array}$ \\
\hline & $\begin{array}{l}\text { Audio a video formáty (druhy, využití, } \\
\text { výhody, nevýhody) }\end{array}$ \\
\hline & Komprimace dat \\
\hline & $\begin{array}{l}\text { Kombinace různých druhů dat v rámci } \\
\text { editorských programů }\end{array}$ \\
\hline & $\begin{array}{l}\text { Změna formátu pomocí různých pro- } \\
\text { gramů }\end{array}$ \\
\hline \multirow{3}{*}{$\begin{array}{l}\text { Žák vysvětlí rozdíl mezi daty a informa- } \\
\text { cemi; vyhodnocuje data a informace; od- } \\
\text { haluje chyby v cizích interpretacích dat. }\end{array}$} & Data a informace \\
\hline & Získávání dat \\
\hline & Odstranění chybných dat \\
\hline
\end{tabular}

\begin{tabular}{|c|c|}
\hline \multicolumn{2}{|l|}{ Informační systémy } \\
\hline Výstupy & Učivo \\
\hline \multirow[t]{2}{*}{$\begin{array}{l}\text { Žák vymezí problém a určí, zda při jeho } \\
\text { rešení využije evidenci dat. }\end{array}$} & $\begin{array}{l}\text { Vlastní návrh informačního systému } \\
\text { (prvky a vztahy mezi nimi) }\end{array}$ \\
\hline & $\begin{array}{l}\text { Popis informačního systému pomocí dia- } \\
\text { gramu }\end{array}$ \\
\hline \multirow{2}{*}{$\begin{array}{l}\text { Žák navrhne a vytvoř́ tabulku pro evi- } \\
\text { denci dat. }\end{array}$} & Tvorba tabulek (formátování) \\
\hline & Vlastnosti správné tabulky \\
\hline \multirow{4}{*}{$\begin{array}{l}\text { Žák nastaví pravidla pro práci se zá- } \\
\text { znamy v evidenci dat. Žák řadí a filtruje } \\
\text { záznamy v tabulce, využívá při práci } \\
\text { s daty v tabulce vzorce a funkce. }\end{array}$} & Způsob evidence dat \\
\hline & Řazení dat \\
\hline & Filtrování dat podle různých parametrů \\
\hline & $\begin{array}{l}\text { Matematické operace, logické a statis- } \\
\text { tické funkce }\end{array}$ \\
\hline
\end{tabular}

\begin{tabular}{|l|l|}
\hline \multicolumn{2}{|l|}{ Algoritmizace a programování } \\
\hline Výstupy & Učivo \\
\hline Žák v blokově orientovaném programo- \\
vacím jazyce sestaví přehledný program
\end{tabular}


pro vyřešení zadaného problému, program otestuje a opraví v něm př́ípadné logické a běhové chyby.

Žák použivá opakování, větvení programu, proměnné, podprogramy s parametry, používá události k paralelnímu spouštění podprogramů.
Oprava chyb algoritmu, ošetření všech možností

Různé způsoby sestavení programu, cykly (využití opakování)

Větvení programu (podmínky KDYŽ) vnořené větvení

Vlastní bloky

Způsoby spuštění programu, paralelní spuštění více částí

Popis algoritmu (slovně, text)

Popis algoritmu (diagramy)

Výstupy algoritmu ritmem řešen.

\begin{tabular}{|c|c|}
\hline \multicolumn{2}{|l|}{ Počítač a jeho ovládání } \\
\hline Výstupy & Učivo \\
\hline \multirow[t]{3}{*}{ Žák využívá paměti. } & $\begin{array}{l}\text { Druhy pamětí - interní, externí, operační } \\
\text { (RAM) }\end{array}$ \\
\hline & Ukládání dat \\
\hline & Zálohování dat \\
\hline \multirow{4}{*}{$\begin{array}{l}\text { Žák vysvětlí možnosti a omezení tech- } \\
\text { nických a programových zabezpečova- } \\
\text { cích řešení, usměrnuje svou činnost tak, } \\
\text { aby minimalizoval riziko ztráty či zneu- } \\
\text { žití dat. }\end{array}$} & Bezpečná hesla, šifrování dat \\
\hline & Autorská práva \\
\hline & Škodlivý software \\
\hline & $\begin{array}{l}\text { Ochrana před škodlivým softwarem (anti- } \\
\text { vir, firewall) }\end{array}$ \\
\hline \multirow{2}{*}{$\begin{array}{l}\text { Žák s vědomím odlišnosti mezi fyzic- } \\
\text { kým a digitálním světem vytváŕí a spra- } \\
\text { vuje svoji digitální identitu. }\end{array}$} & Bezpečné chování na internetu \\
\hline & Riziko sociálních sítí \\
\hline
\end{tabular}

\section{8. ročník}

\begin{tabular}{|l|l|}
\hline Algoritmizace a programování \\
\hline Výstupy & Učivo \\
\hline Žák v blokově orientovaném programo- & Napsání programu \\
\cline { 2 - 2 } $\begin{array}{l}\text { vacím jazyce sestaví přehledný program } \\
\text { pro vyřešení zadaného problému, pro- } \\
\text { gram otestuje a opraví v něm případné }\end{array}$ & $\begin{array}{l}\text { Testování funkčnosti algoritmu za růz- } \\
\text { ných situací }\end{array}$ \\
\cline { 2 - 2 } logické a běhové chyby. & $\begin{array}{l}\text { Oprava logických chyb, ověření správ- } \\
\text { nosti řešení }\end{array}$ \\
\hline Žák používá opakování, větvení pro- & $\begin{array}{l}\text { Efektivnější zápis kódu (kratší, univer- } \\
\text { gramu, promějǔín }\end{array}$ \\
\cline { 2 - 2 } $\begin{array}{l}\text { záné, podprogramy s para- } \\
\text { metry, používá události k paralelnímu } \\
\text { spouštění podprogramů. }\end{array}$ & Větvení, vlastní bloky s parametry \\
\cline { 2 - 2 } & $\begin{array}{l}\text { Způsoby spuštění programu, paralelní } \\
\text { spuštění více částí }\end{array}$ \\
\hline
\end{tabular}




\begin{tabular}{|c|c|}
\hline & $\begin{array}{l}\text { Základy robotiky (vytvoření robota, na- } \\
\text { stavení chování podle požadavků) }\end{array}$ \\
\hline \multirow{2}{*}{$\begin{array}{l}\text { Žák po přečtení jednotlivých kroků algo- } \\
\text { ritmu nebo programu vysvětlí celý po- } \\
\text { stup, určí problém, který je daným algo- } \\
\text { ritmem řešen. }\end{array}$} & $\begin{array}{l}\text { Řazení částí algoritmu (logická posloup- } \\
\text { nost) }\end{array}$ \\
\hline & Znázornění algoritmu pomocí diagramů \\
\hline \multirow{3}{*}{$\begin{array}{l}\text { Žák navrhne různé algoritmy pro řešení } \\
\text { problému, vybere } z \text { více možností } \\
\text { vhodný algoritmus pro řešený problém } \\
\text { a svůj výběr zdůvodní. }\end{array}$} & $\begin{array}{l}\text { Algoritmy - různé postupy vedoucí ke } \\
\text { stejnému výsledku }\end{array}$ \\
\hline & Porovnávání algoritmů \\
\hline & $\begin{array}{l}\text { Výběr vhodné podoby algoritmů v sou- } \\
\text { vislosti se zadáním, požadavky či dalším }\end{array}$ \\
\hline \multirow{2}{*}{$\begin{array}{l}\text { Žák upraví daný algoritmus pro jiné pro- } \\
\text { blémy, ověří správnost postupu navrže- } \\
\text { ného i někým jiným, najde a opraví v } \\
\text { něm př́ipadnou chybu. }\end{array}$} & Generalizace algoritmů \\
\hline & $\begin{array}{l}\text { Posuzování funkčnosti hotových algo- } \\
\text { ritmů a jejich vylepšování }\end{array}$ \\
\hline
\end{tabular}

\begin{tabular}{|c|c|}
\hline \multicolumn{2}{|l|}{ Data, informace a modelování } \\
\hline Výstupy & Učivo \\
\hline \multirow{2}{*}{$\begin{array}{l}\text { Žák vyhodnocuje data a informace; odha- } \\
\text { luje chyby v cizích interpretacích dat. }\end{array}$} & Souvislosti mezi informacemi \\
\hline & Zpracování informací \\
\hline \multirow{3}{*}{$\begin{array}{l}\text { Žák vymezí problém a určí, jaké infor- } \\
\text { mace bude potřebovat k jeho řešení; } \mathrm{k} \text { po- } \\
\text { pisu použivá grafy, př́ípadně další iko- } \\
\text { nické modely. }\end{array}$} & Zpracování syrových dat \\
\hline & Grafy (výsečový, sloupcový, spojnicový) \\
\hline & $\begin{array}{l}\text { Další ikonické modely (vazby a vztahy } \\
\text { mezi informacemi) }\end{array}$ \\
\hline \multirow{4}{*}{$\begin{array}{l}\text { Žák zhodnotí, zda jsou modelu všechna } \\
\text { data potřebná k řešení problému; vyhledá } \\
\text { chybu v modelu a ve vlastním modelu } \\
\text { chybu opraví. }\end{array}$} & $\begin{array}{l}\text { Výběr dat potřebných pro řešení dané si- } \\
\text { tuace }\end{array}$ \\
\hline & Čtení dat z grafických modelů \\
\hline & $\begin{array}{l}\text { Další zpracování informací získaných } \\
\text { z grafického modelu (např. textově, ta- } \\
\text { bulkou) }\end{array}$ \\
\hline & Vypovídající schopnost modelů \\
\hline
\end{tabular}

\begin{tabular}{|c|c|}
\hline \multicolumn{2}{|l|}{ Informační systémy } \\
\hline Výstupy & Učivo \\
\hline \multirow{3}{*}{$\begin{array}{l}\text { Žák vede navrženou evidenci dat, sleduje } \\
\text { dodržování stanovených pravidel a po- } \\
\text { stupů, hodnotí fungování evidence, } \\
\text { opraví chyby, př́padně navrhne vylep- } \\
\text { šení. }\end{array}$} & Způsob správné a přehledné evidence dat \\
\hline & Vztahy mezi tabulkami \\
\hline & $\begin{array}{l}\text { Chyby v evidenci dat (duplikace dat, } \\
\text { chybné hodnoty) }\end{array}$ \\
\hline
\end{tabular}

\section{9. ročník}

\begin{tabular}{|l|l|}
\hline Data, informace a modelování \\
\hline Výstupy & Učivo \\
\hline
\end{tabular}




\begin{tabular}{|c|c|}
\hline \multirow{2}{*}{$\begin{array}{l}\text { Žák při digitalizaci zvolí formát vhodný } \\
\text { pro přenos a uchovávání informací } \\
\text { a svou volbu zdo̊vodní; v př́padě potřeby } \\
\text { vhodně kombinuje data různého typu. }\end{array}$} & $\begin{array}{l}\text { Rizika při přenosu dat (možnost ztráty, } \\
\text { nekompatibilita využívaných programù } \\
\text { uživateli) }\end{array}$ \\
\hline & $\begin{array}{l}\text { Formáty vhodné pro přenos dat (CSV, } \\
\text { XML) }\end{array}$ \\
\hline $\begin{array}{l}\text { Žák k řešení problému používá grafy, pří- } \\
\text { padně další ikonické modely. }\end{array}$ & $\begin{array}{l}\text { Zvolení vhodného modelu pro výstižné } \\
\text { znázornění dané situace }\end{array}$ \\
\hline \multirow{3}{*}{$\begin{array}{l}\text { Žák zhodnotí, zda jsou modelu všechna } \\
\text { data potřebná k řešení problému; porovná } \\
\text { svůj navržený model s jinými modely } \\
\text { k řešení stejného problému a vybere } \\
\text { vhodnější, svou volbu zdůvodní. }\end{array}$} & Vypc \\
\hline & Porovn \\
\hline & $\begin{array}{l}\text { Vybrání vhodného modelu podle kritérií } \\
\text { (např. přehlednost, obsáhlost, způsob } \\
\text { znázornění) }\end{array}$ \\
\hline
\end{tabular}

\begin{tabular}{|c|c|}
\hline \multicolumn{2}{|l|}{ Algoritmizace a programování } \\
\hline Výstupy & Učivo \\
\hline \multirow{2}{*}{$\begin{array}{l}\text { Žák v blokově orientovaném programo- } \\
\text { vacím jazyce sestaví přehledný program. }\end{array}$} & Napsání komplexnějš́ích programů \\
\hline & Rozsáhlejší projekty \\
\hline \multirow{5}{*}{$\begin{array}{l}\text { Žák používá opakování, větvení pro- } \\
\text { gramu, proměnné, podprogramy s para- } \\
\text { metry. }\end{array}$} & Vlastní proměnné, seznamy \\
\hline & Bloky, parametry \\
\hline & Vnořené funkce \\
\hline & $\begin{array}{l}\text { Způsoby spuštění programu, paralelní } \\
\text { spuštění více částí }\end{array}$ \\
\hline & $\begin{array}{l}\text { Robotika (vytvoření robota, naprogramo- } \\
\text { vání chování podle požadavků, využívání } \\
\text { vstupních podmínek) }\end{array}$ \\
\hline \multirow{3}{*}{$\begin{array}{l}\text { Žák navrhne různé algoritmy pro řešení } \\
\text { problému, vybere z více možností } \\
\text { vhodný algoritmus pro řešený problém } \\
\text { a svůj výběr zdůvodní. }\end{array}$} & $\begin{array}{l}\text { Porovnávání různých algoritmických ře- } \\
\text { šení }\end{array}$ \\
\hline & Různé algoritmy sloužící stejnému účelu \\
\hline & $\begin{array}{l}\text { Výběr algoritmu podle předem daných } \\
\text { požadavků }\end{array}$ \\
\hline \multirow{3}{*}{$\begin{array}{l}\text { Žák upraví daný algoritmus pro jiné pro- } \\
\text { blémy, ověří správnost postupu navrže- } \\
\text { ného i někým jiným, najde a opraví } \\
\text { v něm případnou chybu. }\end{array}$} & Zobecňování algoritmů pro další využití \\
\hline & $\begin{array}{l}\text { Posuzování funkčnosti již vytvořených } \\
\text { algoritmů }\end{array}$ \\
\hline & $\begin{array}{l}\text { Opravování logických chyb v algorit- } \\
\text { mech }\end{array}$ \\
\hline
\end{tabular}

\begin{tabular}{|c|c|}
\hline \multicolumn{2}{|l|}{ Počítač a jeho ovládání } \\
\hline Výstupy & Učivo \\
\hline \multirow{4}{*}{$\begin{array}{l}\text { Žák určí charakteristické parametry počí- } \\
\text { tačů v různých zařizeních i typických } \\
\text { ćástí počítačových soustav. }\end{array}$} & Co vše určuje výkonný počítač? \\
\hline & Hlavní části počítače \\
\hline & Procesor, grafická karta \\
\hline & Druhy pamětí \\
\hline \multirow[t]{2}{*}{$\begin{array}{l}\text { Žák popíše typické úkoly OS jako pro- } \\
\text { středníkủ mezi uživatelem a počítačem. }\end{array}$} & $\begin{array}{l}\text { Princip zpracovávání informací v PC (di- } \\
\text { gitalizace) }\end{array}$ \\
\hline & Multitasking \\
\hline
\end{tabular}




\begin{tabular}{|c|c|}
\hline & Způsob řazení úkonů v počítači \\
\hline \multirow{2}{*}{$\begin{array}{l}\text { Žák si poradí s typickými závadami } \\
\text { a chybovými stavy počítačù. }\end{array}$} & Správce úloh \\
\hline & Chyby při instalaci \\
\hline \multirow{5}{*}{$\begin{array}{l}\text { Žák uvede př́iklady sítí a popíše jejich } \\
\text { charakteristické znaky, vybírá nejvhod- } \\
\text { nější způsob k připojení digitálních zaří- } \\
\text { zení do počítačové sítě. }\end{array}$} & Server vs. klientské počítače \\
\hline & $\begin{array}{l}\text { Princip fungování školní sítě (práva, pře- } \\
\text { nos dat, místo na disku) }\end{array}$ \\
\hline & Druhy počítačových sítí a jejich využití \\
\hline & Тур \\
\hline & Možn \\
\hline \multirow{4}{*}{$\begin{array}{l}\text { Žák se orientuje ve vývoji digitálních } \\
\text { technologií a popíše, jak zmenny ovlivnily } \\
\text { postupy v běžném životě, u předpoklá- } \\
\text { daných trendů zhodnotí př́nos a rizika } \\
\text { změn. }\end{array}$} & $\begin{array}{l}\text { Využití digitálních technologií v různých } \\
\text { sférách }\end{array}$ \\
\hline & Změny v systému díky DT \\
\hline & Výhody využív \\
\hline & Rizika a nevýhody při využití DT \\
\hline
\end{tabular}

\section{Závěr}

Informatika je v novém RVP vnímána nikoliv jako obsluha počítače, ale jako obor všeobecného vzdělávání, rozvíjející mentální a kognitivní vlastnosti jedince, podobně jako to dělá matematika a prírodní vědy (Vaníček, 2018).

V rámci výuky ICT se po uvedení nového RVP pro základní vzdělávání v oficiální platnost budou učitelé zabývat především programováním, algoritmizací, logikou v podobě tvorby modelů nebo informačních systémů. Rozšǐření je také $\mathrm{v}$ zaměření na různé druhy digitálních technologií, které od vydání minulého RVP v r. 2005 značně pokročily.

Jelikož je množství informatických témat daleko rozsáhlejší než doposud a některá aktuální témata $\mathrm{v}$ novém RVP obsažená nejsou, budeme $\mathrm{v}$ další fázi vytvářet i návrh ŠVP pro vzdělávací okruh Využití digitálních technologií (vzdělávací oblast Člověk a svět práce), naplněný zejména tvorbou a zpracováním multimédií, tvorbou webových stránek a rastrovou, vektorovou či 3D grafikou. Návrh bude předpokládat výuku ve dvou ročních 2. stupně s časovou dotací 0,5 hodiny týdně, která může být dotována $\mathrm{z}$ disponibilních hodin.

ŠVP bývají většinou obecnějšího charakteru, a to proto, aby nevznikala nutnost jejich úprav při každé drobnější výukové změně, např̀. ve spojitosti s využitím jiného softwaru nebo učebních pomůcek. Přesto je ale pro začínající i zkušenější učitele podstatné, jaké programy lze využívat či jaká podtémata a typy úloh zařadit do výuky. Touto problematikou se v rámci výše zmíněného projektu zabýváme také a konkretizujeme jednotlivé výstupy navrženého ŠVP. Tyto návrhy budou následně podpořeny několika videohospitacemi, ve kterých bude názorně předvedena výuka aktuálních informatických témat, především výuka programování v prostředí Scratch, využití robotiky, cloudových služeb a tvorba webových stránek.

Posledním tématem, které by také mělo být součástí každého ŠVP a na kterém pracujeme, jsou možná prưřezová témata a př́ípadné mezipředmětové vztahy.

Návrh vzorového ŠVP úzce souvisí s plánovanou významnou proměnou výuky informatiky, tedy přechodem od uživatelských dovedností a mechanického ovládání př̀vážně kancelářských softwarových produktů $\mathrm{k}$ tvůrčí činnosti žáků a studentů, $\mathrm{k}$ príklonu $\mathrm{k}$ algoritmizaci, programování, modelování a informačním systémům, tedy tématům, která v dosud platném RVP vůbec obsažena nebyla. Naše návrhy tedy budou v blízké budoucnosti 
velmi užitečné autorům nových ŠVP na základních školách a víceletých gymnáziích, resp. se jimi školy mohou v budoucnu inspirovat.

Na úplný závěr článku aktuální informace, která byla zveřejněna těsně před jeho odesláním: „Osnovy v úterý (pozn. autora - 28. 8. 2018) schválilo vedení ministerstva školství a od príštího týdne se podle nich začne výuka testovat ve vybraných 70 školách. Když testováni proběhne bez problémů, do dvou let by měly být nové vzdělávací plány pro informatiku závazné pro všechny základni školy“"(Respekt, 2018).

\section{Literatura}

Acer: International Computer and Information Literacy Study [online]. (2018). [cit. 201806-29]. Dostupné z: https://icils.acer.org/.

Bělecký, Z. (2007). Klíčové kompetence v základním vzdělávání. Praha: Výzkumný ústav pedagogický.

European Commission. DigComp 2.0: The Digital Competence Framework for Citizens [online]. (2017). [cit. 2017-07-15]. Dostupné z: https://ec.europa.eu/jrc/en/publication/eur-scientific-and-technical-research-reports/digcomp-20-digital-competence-framework-citizens-update-phase-1-conceptual-reference-model.

Ferrari, A. (2012). Digital Competence in Practice: An Analysis of Frameworks [online]. European Commission, Institute for Prospective Technological Studies. Dostupné z: ftp.jrc.es/EURdoc/JRC68116.pdf.

Charalambidis, A. (2005). Manuál pro tvorbu školních vzdělávacích programů v základním vzdělávání. Praha: VúP.

Info.edu.cz: Portál o školství a vzdělávání [online]. (2010). [cit. 2018-01-20]. Dostupné z: http://info.edu.cz/.

Kalaš, I. (2013). Premeny školy v digitálnom veku. Slovenské pedagogické nakladatel'stvo - Mladé letá.

Lessner, D. (2014). Analýza významu pojmu ,,computational thinking. In: Journal of Technology and Information Education, 6 (1), Olomouc, pp. 71-88. Dostupné z: http://www.jtie.upol.cz/pdfs/jti/2014/01/06.pdf.

Metodický portál RVP.cz [online]. (2012). Praha [cit. 2018-01-24]. Dostupné z: http://rvp.cz/.

MŠ̉MT. (2005). Rámcový vzdèlávací program pro základni vzdèlávání. Praha: VÚP.

MŠMT. (2007). Rámcový vzdèlávaci program pro gymnázia. Praha: VÚP.

MŠMT. (2016). Rámcový vzdélávaci program pro základni vzdélávání. Praha: MŠMT.

Národní ústav pro vzdělávání. (2018). Revize RVP v oblasti Informatiky a informačních a komunikačnich technologií [online]. Praha. [cit. 2018-01-24]. Dostupné z: http://www.nuv.cz/ revize-rvp-ict.

Pedagogické.info [online]. (2007). [cit. 2017-06-29]. Dostupné z: http://www.pedagogicke.info/.

Respekt. (2018). Začiná revoluce ve výuce informatiky [online]. Respekt [cit. 2018-08-31]. Dostupné z: https://www.respekt.cz/.

Schubert, S. \& Schwill, A. (2011). Didaktik der Informatik. Switzerland: Springer Nature. Vaníček, J. (2018). Jak budou vypadat a kde se vezmou učebnice informatiky podle nových $R V P$ [přednáška]. Nové Město na Moravě: Gymnázium Vincence Makovského, 27.-29. 3. Vlčková, K. (2005). Nová struktura kurikulárních dokumentů v ČR [online]. [cit. 2017-0629]. Dostupné z: https://is.muni.cz/el/1411/jaro2005/MFPE0821/um/struktura kurikularnich dokumentu cr.pdf?lang=cs. 